Ekspansi: Jurnal Ekonomi, Keuangan, Perbankan dan Akuntansi

ISSN (Online): 2580-7668 ISSN (Print): 2085-5230

Vol. 13, No. 1 (Mei 2021), Hal. 67 - 82

\title{
PENGUJIAN PEMBIAYAAN MUSYARAKAH SEBAGAI VARIABEL INTERVENING ANTARA DANA PIHAK KETIGA (DPK) TERHADAP LABA BERSIH PADA BANK UMUM SYARIAH PERIODE 2017-2019
}

\author{
Meilinda Anggreni ${ }^{1}$, Ira Novianty ${ }^{2}$ \\ 1,2 Prodi S-2 Keuangan dan Perbankan Syariah, Politeknik Negeri Bandung, Bandung, \\ Indonesia \\ Email Korespondensi: meilinda.anggraeni.kps20@polban.ac.id
}

\begin{abstract}
This study aims to discover the effect of third party funds on net profit with musyarakah financing as intervening variable in the syariah commercial banks in the period 2017-2019. The type of data is secondary data. The data source is in the from of annual reports of syariah commercial banks. In this study, used 14 syariah banks as samples. Quantitative research methods are used this research. The sampling used purposive sampling and the data analysis of this research is assumption test analysis and path analysis. The results of this research shows that (1) third party funds has impact on the musyarakah financing. Because, the main source of funding in the distribution of musyarakah financing is DPK, (2) third party funds has impact on the net profit. Because the allocation of DPK to financing certainly results in a financing advantage that maximizes net profit, (3) musyarakah financing has impact on the net profit. Because musyarakah financing has the potential to earn profits so as to increase net profit, (4) musyarakah financing variable can mediate third party funds on the net profit. Islamic banking uses the collected funds to be then reallocated to the product distribution of musyarakah financing to maximize net profit income.
\end{abstract}

Keywords: Third Party Funds, Musyarakah Financing, Net Profit

Abstrak: Penelitian ini bertujuan untuk mengetahui pengaruh dana pihak ketiga terhadap laba bersih dengan pembiayaan musyarakah sebagai variabel intervening pada Bank Umum Syariah (BUS) di Indonesia periode 2017-2019. Jenis data yang digunakan yaitu data sekunder, Sumber data berupa laporan keuangan tahunan Bank Umum Syariah. Dalam penelitian ini menggunakan 14 BUS sebagai sampel. Metode kuantitatif digunakan dalam penelitian ini. Pengambilan sampel menggunakan purposive sampling dan analisis data yang digunakan dalam penelitian ini yakni uji asumsi klasik dan analisis jalur. Hasil penelitian ini yaitu (1) dana pihak ketiga mempengaruhi pembiayaan musyarakah. Sebab, sumber pendanaan utama dalam penyaluran dana akad musyarakah yakni DPK, (2) dana pihak ketiga mempengaruhi laba bersih. Sebab, pengalokasian DPK pada pembiayaan tentunya menghasilkan keuntungan pembiayaan yang memaksimalkan pendapatan laba bersih, (3) pembiayaan musyarakah mempengaruhi laba bersih. Sebab, pembiayaan musyarakah berpotensi mendapatkan keuntungan sehingga meningkatkan pendapatan laba bersih, (4) variabel pembiayaan musyarakah dapat memediasi dana pihak ketiga terhadap laba bersih. Perbankan Syariah memakai dana yang dikumpulkan untuk kemudian dialokasikan kembali pada produk penyaluran dana akad musyarakah tentunya untuk memaksimalkan pemasukan laba bersih.

Kata Kunci: Dana Pihak Ketiga (DPK), Pembiayaan Musyarakah, Laba Bersih 


\section{PENDAHULUAN}

Bank sebagai financial intermediary mempunyai peranan yang sangat penting bagi masyarakat. PSAK No. 31 menerangkan bahwa Bank berperan menjembatani dan memfasilitasi antara masyarakat yang menyimpan dana dengan masyarakat yang menggunakan dana. Selain itu juga berperan memperlancar segala arus pembayaran. Dilihat dari definisi diatas, maka perusahaan perbankan berperan menyimpan dana dalam bentuk tabungan, giro maupun deposito. Kemudian hasil penghimpunan tersebut disalurkan kembali melalui berbagai produk pembiayaan bagi nasabah yang membutuhkan dengan sesuai kriteria yang telah ditentukan.

Kemampuan pengelolaan dana simpanan (DPK) yang baik harus ada pada perusahaan perbankan. Hal ini akan mempengaruhi pembiayaan yang akan disalurkan pada masyarakat yang membutuhkan dana serta berpengaruh pula terhadap laba yang akan didapatkan oleh perusahaan perbankan itu sendiri. Setiap Bank Syariah sudah memiliki strategi dan rencana jangka panjang dalam upaya mengelola bisnisnya (Chandra et al., 2019). Strategi tersebut akan berkaitan dengan kesehatan suatu bank yang memberikan gambaran atas kinerja perbankan syariah saat ini ataupun kinerja pada waktu yang akan datang. Indikator utama untuk menilai sehat atau tidaknya bank yakni berdasarkan pendapatan laba yang diterima pihak bank. Hal ini kembali lagi pada tujuan bank syariah yaitu dapat mengoptimalkan laba.

Menurut Merliana and Fitri (2016), kemampuan bank yang berhasil memperoleh laba yang optimal akan menarik berbagai pihak untuk menggunakan jasa perbankan itu sendiri. Semisal investor yang tentu akan menilai kelayakan bank atas keberhasilan suatu bank dalam menghasilkan pendapatan laba yang optimal. Ketika kinerja yang baik sudah ditunjukan oleh perbankan syariah, tentunya kepercayaan masyarakat meningkat. Peningkatan ini kemudian akan mempengaruhi jumlah penghimpunan dana masyarakat yang berhasil dihimpun oleh pihak bank Syariah. Pengimpunan dana masyarakat inilah yang menjadi salah satu faktor dalam upaya pihak bank Syariah dalam meningkatkan pertumbuhan laba. (Widyastuti and Hendrieanto, 2010).

Laba bersih seringkali digunakan sebagai ukuran kinerja, pengukuran tingkat kesehatan maupun sebagai dasar pengukuran kesuksesan atau keberhasilan sebuah perusahaan dalam periode tertentu (Putra and Djazari., 2019). Secara umum laba bersih adalah suatu ringkasan dari hasil bersih aktivitas operasional perusahaan dalam suatu periode tertentu. Oleh sebab itu, setiap bank syariah harus berusaha mengoptimalkan pendapatan laba agar mendapatkan persepsi yang baik dimata masyarakat, sehingga bisa meningkatkan kepercayaan masyarakat terhadap bank.

Lembaga independen yang mengawasi perusahaan perbankan (OJK) merilis statistik yang menunjukan bahwa 14 bank umum Syariah pada kuartal III/2020 berhasil memperoleh kenaikan laba bersih. Total laba bersih yang diperoleh bank syariah sebesar Rp 2,68 triliun per kuartal III 2020 atau turun 9,25 persen seacara year on year. Dari jumlah tersebut separuh bank umum syariah mencetak kenaikan, sedangkan sisanya membukukan penurunan laba. Jika melihat nila laba secara nominal, Bank Syariah Mandiri (BSM) berhasil memperoleh pendapatan laba terbesar yakni Rp 1,07 triliun atau tumbuh 22,66 persen. Disisi lain, Bank Panin Dubai Syariah 
harus mengalami penurunan laba sebesar 97,05 persen menjadi Rp 244 juta (Sumber: Bisnis.com). Fenomena mengenai kenaikan ataupun penurunan laba yang terjadi dalam suatu perusahaan perbankan sangatlah menimbulkan permasalahan yang berdampak besar pada kinerja keuangan bank syariah itu sendiri terkhusus pada pendapatan laba bersih (net profit income).

Beberapa peneliti telah melakukan kajian mengenai variabel yang berpengaruh terhadap laba bersih. Dalam pengujian ini mengungkapkan variabel yang berpengaruh terhadap laba bersih antara lain DPK dan pembiayaan musyarakah.

Destiana (2016) dalam penelitiannya mengemukakan bahwa sumber pendanaan bank yang paling utama diperoleh melalui DPK tersebut, oleh sebab itu tingginya dana simpanan masyarakat pada perusahaan perbankan berdampak pula pada pinjaman yang akan diberikan kepada masyarakat. Hal ini tidak selaras dengan penelitian Muhammadinah (2020) yang menunjukkan hasil DPK tidak mempengaruhi pembiayaan myusyarakah.

Nirwana and Septiarini (2015) dalam penelitiannya menyatakan bahwa Bank Syariah harus mampu menghimpun dana sebesar dana yang akan disalurkan. Jika dana belum mencukupi maka target penyaluran pembiayaan oleh bank syariah tidak dapat berjalan sesuai dengan harapan. Disisi lain, Muhammadinah (2020) berpendapat dalam penelitiannya bahwa tidak terdapat pengaruh variabel DPK terhadap laba bersih. Adanya peningkatan penghimpunan DPK belum tentu dapat menggambarkan pendapatan laba yang diperoleh semakin besar. Kondisi tersebut akan menimbulkan ketakseimbangan simpanan yang berhasil dihimpun dengan jumlah pengalokasian pembiayaan kepada masyarakat.

Winarto and Nuraisyah (2019) menyatakan ketika pendapatan dari bagi hasil musyarakah pada suatu bank mengalami peningkatan tentunya laba bersih juga akan meningkat begitupun sebaliknya. Tingginya tingkat pendapatan bagi hasil musyarakah yang disalurkan secara efektif dan efisien melalui pembiayaan berdampak pada peningkatan laba bersih. Tetapi hal ini tidak sejalan dengan penelitian (Monika, 2019) hasil pengujian menunjukkan bahwa penyaluran dana kepada masyarakat tidak mempengaruhi perolehan laba bersih, karena penyaluran dana yang diberikan terhadap masyarakat dalam menjalankan sebuah usaha tertentu akan berpotensi menghasilkan keuntungan ataupun kerugian yang bersifat belum pasti serta tidak tetap.

Berdasarkan latar belakang, fenomena-fenomena yang ada dan berbagai hasil riset sebelumnya, maka orisinalitas penelitian ini didasarkan pada orisinalitas model empiris. Orisinalitas model penelitian empiris dalam penelitian ini yakni pembiayaan musyarakah sebagai variabel intervening (mediasi) dalam hubungan antara variabelvariabel yang mempengaruhi dana pihak ketiga (DPK) dengan laba bersih. Berbeda dengan riset sebelumnya, yang pada umumnya lebih menekankan pada hubungan kausalitas antara variabel pembiayaan musyarakah dan laba bersih sebagai variabel dependen ataupun variabel independen.

Dari kajian sebelumnya, penulis tertarik pada fenomena yang mepengaruhi peningkatan ataupun penurunan laba bersih suatu perusahaan perbankan. Karena sebab itu, fenomena tersebut dijadikan suatu riset berjudul "Pengujian Pembiayaan 
Musyarakah Sebagai Variabel Intervening Antara Dana Pihak Ketiga (DPK) Terhadap Laba Bersih Pada Bank Umum Syariah Periode 2017-2019”.

\section{TINJAUAN PUSTAKA}

\subsection{Dana Pihak Ketiga (DPK)}

DPK merupakan simpanan dana masyarakat yang menjadi pendanaan tertinggi pada kegiatan operasional suatu bank. Perusahaan perbankan bisa menggunakan simpanan dana nasabah yang berhasil dikumpulkan untuk setelah itu dialokasikan kembali melalui pembiayaan tentunya dapat meningkatkan pendapatan suatu bank. Pembiayaan pada perbankan akan semakin berkembangan seiring dengan meningkatnya penghimpunan dana pihak ketiga. Masyarakat dapat menyimpan dana yang mereka miliki pada produk simpanan yang ditawarkan bank syariah (Lisa, 2016).

Aturan pada UU RI No.21 Tahun 2008 menerangkan "simpanan adalah dana yang dipercayakan oleh nasabah kepada Bank Syariah dan/atau Unit Usaha Syariah berdasarkan akad wadiah atau akad lain yang tidak bertentangan dengan Prinsip Syariah dalam bentuk giro, tabungan, atau bentuk lainnya yang dipersamakan oleh itu”. Guna menjalankan fungsinya bank memiliki beberapa jenis produk simpanan. Adapun produk simpanan yang terdapat pada bank syariah, ialah simpanan giro (demand deposit), simpanan tabungan (saving deposit) dan simpanan deposito (time deposit). Perbedaan ketiga produk simpanan tersebut yakni waktu penarikannya.

Bank merupakan suatu wadah perantara keuangan ditengah masyarakat, dalam arti lain bank menjembatani atau memfasilitasi masyarakat yang menyimpan dengan masyarakat yang meminjam dana dengan berbagai produk yang dimilikinya. Reputasi baik yang dimiliki bank karena telah menyelenggarakan sebaik-baiknya permasalahan keuangan dapat meningkatkan kepercayaan masyarakat, dan hal ini menjadi harapan setiap bank (Aziza and Mulazid, 2017). Tolok ukur keberhasilan suatu bank dalam akivitas operasional yakni jika bank dapat membiayai operasinya dari sumber dana yang telah berhasil dihimpun. DPK merupakan salah satu dana utama dan terpenting suatu bank. Adapun menurut Aziza and Mulazid (2017) DPK dirumuskan sebagai berikut:

\section{DPK $=$ Giro + Deposito + Tabungan}

\subsection{Pembiayaan Musyarakah}

Pembiayaan adalah suatu kegiatan penyaluran kepada pihak selainselain bank dengan berlandaskan prinsip dalam syariat islam. Pembiayaan sangat berbeda ataupun tidak sama dengan kredit pada bank konvensional, sebab return atas pembiayaan bukan berupa bunga seperti bank konvensional pada umumnya. Produk penyaluran dana pada perbankan syariah yang membagikan hasil sangat besar diantara wujud penyaluran dana lainnya ialah pembiayaan (Elidar et al., 2020). Adapun produk unggulan yang ada pada perbankan syariah ialah pembiayaan dengan akad kerjasama (musyarakah).

Definisi musyarakah berdasarkan Pernyataan Standar Akuntansi Keuangan 106 (PSAK 106) tentang akuntasi musyarakah bahwa "musyarakah merupakan suatu akad 
kerjasama beberapa pihak, dimana setiap pihak memberikan kontribusi dana dengan syarat yang sudah ditetapkan sebelumnya bahwa keuntungan dibagi kepada setiap pihak dengan berdasarkan kesepakatan begitu pula dengan kerugian juga dilimpahkan kepada setiap pihak berdasarkan kontribusi dana yang telah diberikan”. Musyarakah diklasifikasikan kedalam 2 bagian yakni permanen dan menurun. Pembagian dana seluruh pihak berdasarkan pada akad yang sudah disepakati serta jumlah dana tetap sampai akhir masa akad disebut dengan musyarakah permanen. Sedangkan untuk musyarakah menurun yakni akad dengan pembagian dana antar pihak dipindahkan dengan cara bertahap, sehingga terjadinya perpindahan kepemilikan.

Musyarakah, atau "kemitraan", didefinisikan sebagai kontrak kerjasama dalam menyumbangkan modal pada pembiayaan sebuah proyek (Abdul Rahman, Mohd Nor and Salmat, 2020). Semua pihak yang melakukan kerjasama berbagi keuntungan berdasarkan persentase yang sebelumnya sudah disepakati. Sedangkan untuk kerugian sendiri juga sesuai dengan persentase modal yang diberikan oleh pihak yang bekerjasama. Biasanya kontrak pembiayaan akad musyarakah ditawarkan untuk pendanaan modal kerja pengusaha, aset tetap serta pembiayaan proyek.

Dalam transaksi musyarakah, pembiayaan hanya diberikan kepada nasabah yang mempunyai usaha produktif. Sehingga diharapkan memiliki peran besar dalam peningkatan ekonomi pada masyarakat luas. Adanya produk-produk pembiayaan pada bank syariah dapat membangun hubungan kemitraan atanra nasabah dengan pihak bank (Aziza and Mulazid, 2017). Adapun rumus pembiayaan musyarakah menurut (Almunawwaroh and Marlina, 2017), yaitu:

\section{Musvarakah $=$ Ln Pembiayaan Musvarakah}

\subsection{Laba Bersih}

Laba dalam kegiatan bisnis diartikan sebagai suatu selisih kelebihan pendapatan atas beban. Dalam perbandingannya, jika suatu beban dalam perusahaan lebih besar daripada pendapatan maka selisihnya dapat disebut dengan kerugian (Lidyah et al., 2019).

Persentase kenaikan laba pada perusahaan ialah suatu peningkatakan maupun penyusutan laba periode per tahun. Perusahaan memiliki tujuan utama yakni mengoptimalkan pendapatan atau perolehan laba. Adapun perbandingan diantara laba terlaksana yang timbul sepanjang satu periode dengan pengeluaran adalah suatu penafsiran laba secara operasional (Merliana and Fitri, 2016).

Laba bersih merupakan laba operasi dikurangi dengan beban lain-lain serta beban pajak. Pertumbuhan laba bersih merupakan suatu peningkatan ataupun penyusutan laba sesudah dikenakan pajak sepanjang periode tertentu. Tujuan utama perusahan ialah mendapatkan keuntungan sebesar- besarnya. Islam sangat menekankan pendayahgunaan harta serta melarang terjadinya penimbunan harta yang dimiliki. (Fatmawati, Puspitasari and Singgih, 2016). Ketika investor pasar modal ingin menanamkan dana atau modal dalam suatu investasi, maka laba bersih menjadi suatu 
pertimbangan yang dilihat (Bernardin and Pebryyanti, 2016). Adapun rumus laba bersih menurut Chandra et al., (2019), yaitu:

\section{Laba Bersih = Laba Operasi - Beban Lain-Lain - Pajak}

\subsection{Kerangka Konseptual}

Berdasarkan uraian yang telah dijelaskan serta didukung literature review, maka dirumuskan dalam model konseptual, yaitu sebagai berikut:

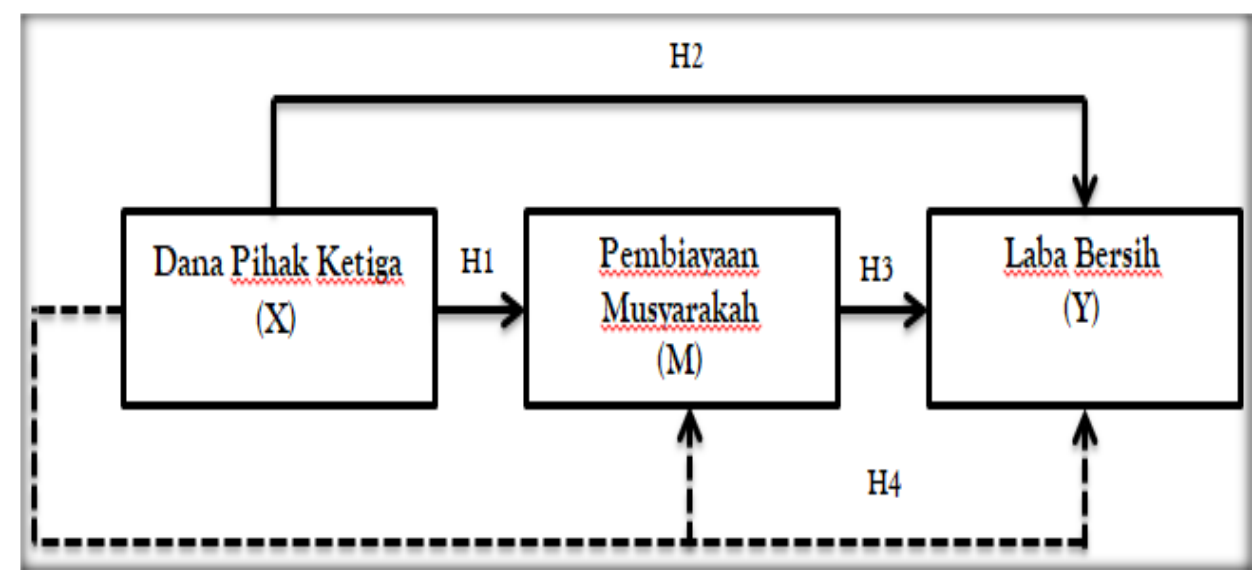

Gambar 1. Kerangka Konsep

\subsection{Pengembangan Hipotesis}

\section{Pengaruh DPK terhadap Pembiayaan Musyarakah}

Komponen utama pada perusahaan perbankan yakni DPK. Dalam dunia perbankan, setiap bank bersaing untuk menghimpun kelebihan dana yang dimiliki masyarakat (surplus unit), agar bisa disalurkan atau dialokasikan kembali. Hal ini bukan tanpa sebab melainkan dengan adanya DPK, perusahaan perbankan sebagai intermediasi dapat berfungsi dengan baik (Setiawan, 2015). Karna sebab itu, DPK mempengaruhi pembiayaan musyarakah. Penelitian Muhammadinah, (2020) menunjukkan bahwa DPK mempengaruhi pembiayaan musyarakah. Hal serupa juga dinyatakan dalam penelitian Destiana (2016), Hasrina and Dasmi (2019), dan Sumadi and Romdhoni (2020). Berdasarkan uraian diatas dapat dirumuskan hipotesis:

H1: DPK berpengaruh terhadap Pembiayaan Musyarakah

\section{Pengaruh DPK terhadap Laba Bersih}

Mengingat perusahaan perbankan sebagai intermediasi, keberadaan DPK sangatlah mempengaruhi kelangsungan bisnis serta mendapatkan perhatian serius pada kegiatan operasional bank syariah (Merliana and Fitri, 2016). Tingginya dana yang berhasil dihimpun, akan memberikan peluang bagi bank syariah untuk menyalurkan kembali pada aset-aset produktif misalnya pada sektor pembiayaan ataupun kegiatan bisnis lainnya. Hal ini akan meningkatkan perolehan laba bersih 
bank syariah. Dalam penelitian (Purwanto, 2011) menunjukan hasil bahwa pembiayaan musyarakah berpengaruh terhadap laba bersih. Selain itu Nirwana and Septiarini (2015), Setiawan and Afrianti (2018), Adawiya (2020), Chandra et al., (2019) dan Muhammadinah, (2020) juga menyatakan hasil serupa dalam penelitian yang telah dilakukannya. Berdasarkan uraian diatas dapat dirumuskan hipotesis:

H2 : DPK berpengaruh terhadap Laba Bersih

\section{Pengaruh Pembiayaan Musyarakah terhadap Laba Bersih}

Fungsi bank dalam penggunaan dana yakni memberikan konstribusi terhadap peningkatan penghasilan. Tingkat penghasilan tertinggi dari bank salah satunya yaitu pembiayaan (Muhammadinah, 2020). Artinya semakin banyak pembiayaan yang disalurkan kepada masyarakat luas, maka akan meningkatkan perolehan laba. Penelitian oleh Monika (2019), Muhammadinah (2020), Nurhamidah and Diana (2021), dan Agustina, Sulaeman and Kartini (2021) menemukan bahwa DPK berpengaruh pada laba bersih. Rumusan hipotesis penelitian yakni:

H3: Pembiayaan Musyarakah berpengaruh terhadap Laba Bersih

\section{Pengaruh Pembiayaan Musyarakah antara DPK terhadap Laba Bersih}

Sumber pendanaan terpenting dan paling utama pada perbankan syariah yakni dana simpanan dari pihak ketiga. Tingginya peningkatan jumlah penghimpunan atau dana simpanan pihak ketiga akan berdampak pada penyaluran atau pengalokasian dana. Bisa diartikan jika jumlah dana pihak ketiga semakin meningkat maka penyaluran dana kepada masyarakat akan meningkat pula. Bank sebagai lembaga perantara haruslah menjalankan fungsinya dengan melakukan pengoptimalan dana yang telah dihimpun (Muhammadinah, 2020). Hasil pengujian Muhammadinah (2020) menemukan bahwa pembiayaan musyarakah dapat memediasi DPK terhadap laba bersih.

H4: Pembiayaan Musyarakah memediasi DPK terhadap Laba Bersih.

\section{METODE PENELITIAN}

Pendekatan kuantiatif dengan data sekunder yakni merupakan tipe penelitian. Laporan tahunan atau annual report diperoleh dari setiap website BUS di Indonesia yang tercatat pada Otoritas Jasa Keuangan (OJK) akan dijadikan data penelitian ini. Adapun referensi lain yaitu artikel ataupun jurnal serta referensi yang berkaitan tentang riset.

Populasi dari penelitian ini yakni keseluruhan Bank Umum Syariah (BUS) di Indonesia yang tercatat pada OJK periode 2017-2019 sejumlah 14 Bank Umum Syariah (BUS). Menurut Sugiyono (2012) purposive sampling yakni metode pemilihan sampel berdasarkan pada kriteria-kriteria khusus, metode pemilihan ini dipakai pada riset ini. Sampel diambil berdasarkan kriteria-kriteria khusus berikut:

1. BUS di Indonesia yang tercatat pada Otoritas Jasa Keuangan (OJK) periode 20172019.

2. BUS di Indonesia yang menerbitkan atau mempublikasikan annual dan financial report selama tahun penelitian 2017-2019. 
3. BUS di Indonesia yang memliki data utuh yang sinkron dengan variabel yang diteliti.

Tabel 1. Definisi Operasional Variabel

\begin{tabular}{|c|l|l|c|}
\hline No. & \multicolumn{1}{|c|}{ Variabel } & \multicolumn{1}{|c|}{ Pengukuran Rumus } & \multicolumn{1}{|c|}{ Skala } \\
\hline 1 & $\begin{array}{l}\text { Dana Pihak } \\
\text { Ketiga (X1) }\end{array}$ & DPK = Giro + Deposito + Tabungan & Rasio \\
\hline 2 & $\begin{array}{l}\text { Pembiayaan } \\
\text { Musyarakah (M) }\end{array}$ & $\begin{array}{l}\text { Musyarakah = Ln Pembiayaan Musyarakah } \\
\text { Rasio }\end{array}$ \\
\hline 3 & Laba Bersih (Y) & $\begin{array}{l}\text { Laba bersih = Laba Operasi - Beban Lain - Lain - } \\
\text { Pajak }\end{array}$ & Rasio \\
\hline
\end{tabular}

Analisa regresi linier multiples, digunakan untuk menguji hipotesis melalui pengujian asumsi klasik guna menentukam ketepatan model. Selain itu, untuk melakukan pengujian variabel intervening maka digunakan analis jalur (path analysis) dengan alat uji IBM SPSS Statitistics 21. Tahapan-tahapan dalam path analysis dapat dilakukan dengan cara berikut:

\section{TAHAP I}

Menetapkan diagram jalur mengikuti pola hubungan variabel berikut ini:

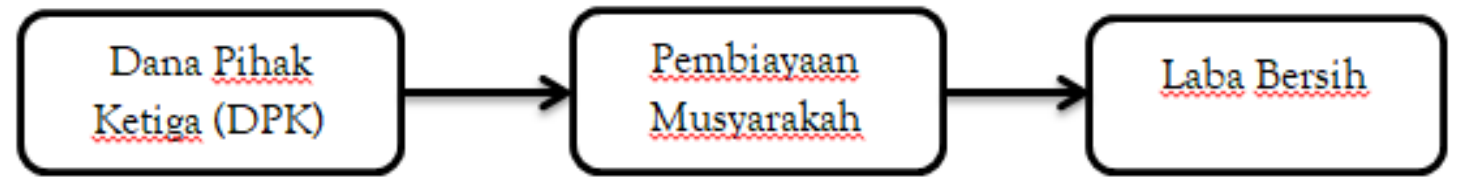

Gambar 2

Diagram Jalur Pengaruh DPK terhadap Laba Bersih dengan Pembiayaan Musyarakah sebagai Variabel Mediasi

\section{TAHAP II}

Menetapkan persamaan structural berikut ini:

Persamaan Sktruktural I:

$\mathrm{M}\left(\right.$ Pembiayaan Musyarakah) $=\beta \mathrm{DKI}+\mathrm{e}_{1}$

Persamaan Struktural II:

$\mathrm{Y}(\mathrm{LABA})=\beta \mathrm{DKI}+\beta$ Pembiayaan Musyarakah $+\mathrm{e}_{1}$

\section{TAHAP III}

Analisis substruktural I dan substruktural II dianalisis menggunakan SPSS versi 21 dengan langkah-langkah berikut ini.

\section{Analisis pada Substruktural I}

Pembiayaan Musyarakah $(\mathrm{M})=\beta \mathrm{DKI}+\mathrm{e}_{1}$

Tahap Menghitung Persamaan Regresi

Mengimplementasikan hasil pada perhitungan SPSS bersumber pada nilai analisis regresi serta menetapkan persamaan struktural sesuai dengan diagram jalus yang ditetapkan.

\section{Analisis Regresi}

1) Mengetahui pengaruh variabel $X$ secara simultan terhadap variabel $M$ 
2) Mengetahui pengaruh variabel $X$ secara parsial terhadap $M$

\section{Analisis pada Substruktural II}

LABA $(\mathrm{Y})=\beta \mathrm{DKI}+\beta$ Pembiayaan Musyarakah $+\mathrm{e}_{1}$

\section{Tahap Menghitung Persamaan Regresi}

Mengimplementasikan hasil pada perhitungan SPSS bersumber pada nilai analisis regresi serta menetapkan persamaan struktural sesuai dengan diagram jalus yang ditetapkan.

\section{Analisis Regresi}

1) Mengetahui pengaruh variabel $X$ dan variabel $M$ secara simultan terhadap variabel Y.

2) Mengetahui pengaruh variabel $X$ dan variabel $M$ secara parsial terhadap variabel Y.

\section{HASIL DAN PEMBAHASAN}

\subsection{Pengujian Asumsi Klasik}

Penelitian ini melakukan beberapa pengujian asumsi klasik yang selanjutnya dibahas dan disajikan pada tabel 2:

Tabel 2. Uji Asumsi Klasik

\begin{tabular}{|c|c|c|c|c|c|c|}
\hline \multirow{2}{*}{ Uji Normalitas } & $1_{1}^{\text {Pers. }}$ & \multicolumn{3}{|c|}{ Asymptotic Significance (2-tailed) } & \multicolumn{2}{|l|}{0,530} \\
\hline & $2^{\text {Pers. }}$ & \multicolumn{3}{|c|}{ Asymptotic Significance (2-tailed) } & \multicolumn{2}{|l|}{0,365} \\
\hline \multirow{2}{*}{ Uji Linearitas } & $1_{1}^{\text {Pers. }}$ & \multicolumn{3}{|c|}{ Signifikansi Deviation from Linearity } & \multicolumn{2}{|l|}{0,065} \\
\hline & $2^{\text {Pers. }}$ & \multicolumn{3}{|c|}{ Signifikansi Deviation from Linearity } & \multicolumn{2}{|l|}{0,089} \\
\hline \multirow{3}{*}{$\begin{array}{l}\text { Uji } \\
\text { Multikollinearitas }\end{array}$} & $1^{\text {Pers. }}$ & $\mathrm{X}$ & $\begin{array}{l}\text { Variance Inflation Factor } \\
\text { (VIF) }\end{array}$ & 1,000 & $\begin{array}{l}\text { Tolerance } \\
\text { (TOL) }\end{array}$ & 1,000 \\
\hline & \multirow{2}{*}{$2^{\text {Pers. }}$} & $\mathrm{X}$ & $\begin{array}{l}\text { Variance Inflation Factor } \\
\text { (VIF) }\end{array}$ & 1,069 & $\begin{array}{l}\text { Tolerance } \\
\text { (TOL) }\end{array}$ & 0,935 \\
\hline & & $\mathrm{M}$ & $\begin{array}{l}\text { Variance Inflation Factor } \\
\text { (VIF) }\end{array}$ & 1,069 & $\begin{array}{l}\text { Tolerance } \\
\text { (TOL) }\end{array}$ & 0,935 \\
\hline \multirow{2}{*}{$\begin{array}{l}\text { Uji } \\
\text { Autokorelasi }\end{array}$} & $1^{\text {Pers. }}$ & \multicolumn{3}{|c|}{ Durbin Watson (DW) } & \multicolumn{2}{|l|}{1,137} \\
\hline & $2^{\text {Pers. }}$ & \multicolumn{3}{|c|}{ Durbin Watson (DW) } & \multicolumn{2}{|l|}{0,604} \\
\hline \multirow{3}{*}{$\begin{array}{l}\text { Uji } \\
\text { Heterokedastisitas }\end{array}$} & $1^{\text {Pers. }}$ & $\mathrm{x}$ & Signifikansi & & 0,442 & \\
\hline & \multirow{2}{*}{ Pers. 2} & $\mathrm{X}$ & \multicolumn{2}{|l|}{ Signifikansi } & \multicolumn{2}{|l|}{0,813} \\
\hline & & $\mathrm{M}$ & Signifikansi & & 0,530 & \\
\hline
\end{tabular}

Hasil statistik SPSS, data diolah 2020

Dapat dilihat dari tabel 2 pada pers. 1 dan pers. 2 yang diujikan didapatkan nilai asymptotic significance (2-tailed) yakni 0,530 pers. 1 dan 0,365 pada pers. 2 nilai keduanya >0,05, maka nilai residual pada pers. 1 maupun 2 terdistribusi normal. Hasil pengujian selanjutnya yakni pengujian linieritas, pada pers. 1 nilai signifikansi $(0,065)$ $>0,05$. Oleh karena itu, terjadinya hubungan linier antar variabel. Kondisi serupa 
terjadi pada pers. 2 dengan nilai signifikansi 0,089 >0,05. Dapat dilihat pula pada tabel 2 bahwa nilai TOL pada pers 1 dan 2 lebih besar dari 0,10 begitu pula dengan VIF lebih kecil dari 10, sehingga pada pers 1 maupun pers. 2 tidak terdapat multikolinieritas. Autokorelasi merupakan hasil uji lainnya, pada pers. 1 sebesar 1,137 dan 0,604 untuk nilai DW pada persamaan 2. Sebuah model regresi dapat dikatakan tidak terjadi autokorelasi jika memenuhi kriteria. Dengan demikian nilai DW dari kedua persamaan diatas berada diantara $-2<\mathrm{DW}<2$, maka tidak terjadi autokolerasi pada model regresi. Pengujian lainnya, tidak terjadi heterokedastisitas pada seluruh output pengujian karna signifikansi pada pers. 1 maupun pers. 2 lebih besar dari 0,05.

Berdasarkan kajian sebelumnya tentang angka dan pembahasan yang diperoleh dari hasil pengujian asusmsi klasik yang telah dilakukan pada riset ini, didapatkan bahwa baik pada pers. 1 maupun pers. 2 riset ini telah memenuji uji asumsi klasik.

\subsection{Uji Hipotesis}

Hasil Pengujian hipotesis yang diteliti yakni:

Tabel 3. Hasil Uji Hipotesis

\begin{tabular}{|l|l|l|l|l|l|l|}
\hline \multirow{2}{*}{$\begin{array}{l}\text { Koefisien } \\
\left(\mathrm{R}^{2}\right)\end{array}$} & Determinasi & Pers. 1 & \multicolumn{2}{|l|}{$\mathrm{R}^{2}$} & \multicolumn{2}{l|}{0,507} \\
\cline { 2 - 7 } & Pers. 2 & \multicolumn{2}{|l|}{$\mathrm{R}^{2}$} & \multicolumn{2}{l|}{572} \\
\hline \multirow{4}{*}{ Uji t } & Substruktur I & $\mathrm{T}$ & $\mathrm{X}$ & 6,076 & Sig. & 0,000 \\
\cline { 2 - 7 } & \multirow{2}{*}{ Substruktur II } & $\mathrm{T}$ & $\mathrm{X}$ & 2,494 & Sig. & 0,018 \\
\cline { 3 - 7 } & & $\mathrm{T}$ & $\mathrm{M}$ & 6,946 & Sig. & 0,000 \\
\hline
\end{tabular}

Hasil statistik SPSS, data diolah 2020

Pada pers. 1 didapatkan $\mathrm{R}^{2}$ yakni 0,507 dan 0,572 pada pers. 2. $\mathrm{R}^{2}$ pers. 1 mempunyai arti secara simultan pengaruh antara DPK dan pembiayaan musyarakah yakni 0,507 atau 50,7\% dengan sisa 49,3\% dipengaruhi oleh variabel di luar model regresi. Sedangkan $\mathrm{R}^{2}$ pers. 2 mempunyai arti secara simultan pengaruh antara DPK dan laba bersih yakni 0,507 atau 50,7\% , dan sisanya yang dipengaruhi variabel lain diluar model regresi yakni 49,3\%.

Hasil uji hipoteris substruktur I hipotesis pertama didapatkan angka t-hitung $(6,076)>$ t-tabel $3(1,68709)$ dan sig. 0,000 < 0,05.Hipotesis kedua substruktur II didapatkan angka thitung $(2,494)>(t$-tabel) 1,68830 dan sig. 0,018<0,05. Selain itu pada substruktur II hipotesis ketiga didapatakan angka (t-hitung) 6,946 > (t-tabel) 1,68830 dan angka signifikansi $0,000<\alpha=0,05$.

Berdasarkan kajian sebelumnya tentang angka dan pembahasan hasil pengujian hipotesis pada uji koefisien determinasi $\left(R^{2}\right)$ pers. 1 serta koefisien determinasi $\left(R^{2}\right)$ pers. 2 maupun uji-t substruktur 1 serta uji-t substruktur II, maka didapatkan suatu kesimpulan bahwa pada riset ini baik pada hipotesis $1(\mathrm{H} 1)$, hipotesis $2(\mathrm{H} 2)$, dan hipotesis 3 (H3) diterima.

\section{Uji Variabel Intervening}

Hasil pengujian variabel mediasi dengan strategy Causal Step pada penelitian yakni sebagai berikut: 


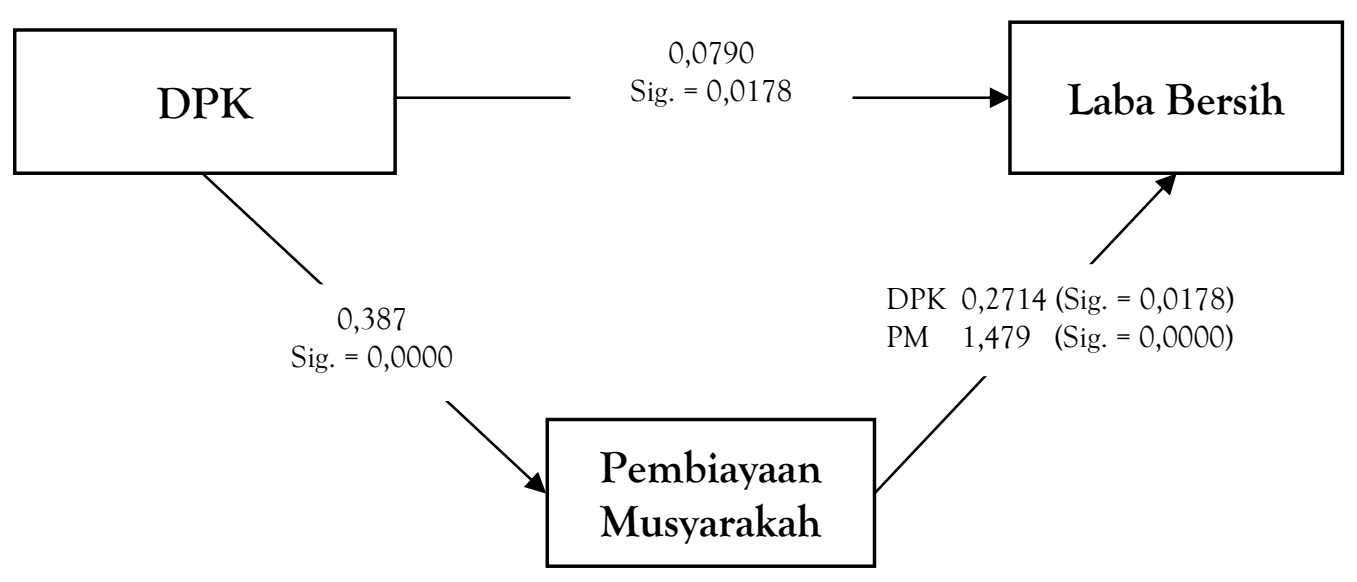

Hasil statistik SPSS, data diolah 2020

Gambar 3. Strategy Causal Step

Hasil analisis strategy Causal Step ditemukan bukti bahwa DPK (X) signifikan $(0,000$ $<0,05)$ terhadap pembiayaan musyarakah $(\mathrm{M})$ dan koefisien regresi $(\mathrm{a})=0,387$. Selanjutnya DPK (X) signifikan $(0,0178)$ terhadap laba bersih $(\mathrm{Y})$ dan koefisien regresi (c) 0,0790. Setelah mengontrol pembiayaan musyarakah (M) dengan nilai signifikansi $0,000<0,05$ dan koefisien regresi (b) $=1,479$ maka variabel DPK signifikan terhadap laba bersih.

Berdasarkan kajian sebelumnya tentang angka serta pembahasan hasil pengujian variabel intervening (mediasi) dengan strategy Causal Step, maka didapatkan suatu kesimpulan bahwa pembiayaan musyarakah mampu memediasi secara partial mediation DPK terhadap laba bersih, sehingga pada riset ini hipotesis 4 (H4) diterima. Sehingga dapat dipastikan adanya hubungan diantara DPK dengan pembiayaan musyarakah.

Pengaruh Dana Pihak Ketiga (DPK) terhadap Pembiayaan Musyarakah

Hasil perhitungan DPK dengan permbiayaan musyarakah didapatkan nilai $\mathrm{t}$ hitung 6,076 dan signifikan t 0,018> $\alpha=0,05$. Hal itu menjelaskan bahwa jika terjadi kenaikan dana pihak ketiga DPK diikuti juga oleh kenaikan pembiayaan musyarakah.

DPK yang mengalami peningkatan akan berpengaruh juga pada kefektifitasan kegiatan operasional bank syariah dalam mengalokasikan ataupun menyalurkan pembiayaan kepada masyarakat yang sedang membutuhkan dana. Bank tidak akan mengabaikan saja dana yang sudah berhasil dihimpun, tetapi bank akan memaksimal dana tersebut untuk disalurkan kembali pembiayaan. Tingginya nilai penyaluran berdampak baik pada keuntungan yang diperoleh bank dari hasil penyaluran tersebut. Bank akan sangat bergantung pada DPK ketika mengalokasikan dana, karena DPK berperan vital bagi bank. Oleh sebab itu, semakin tinggi DPK maka meningkat pula pembiayaan musyarakah yang dialokasikan. Hasil penelitian sejalan dengan Nurjaya (2011), Destiana, (2016), Hasrina and Dasmi, (2019), Sumadi and Romdhoni, (2020). dan Muhammadinah (2020). 


\section{Pengaruh Dana Pihak Ketiga (DPK) terhadap Laba Bersih}

Hasil perhitungan DPK dengan laba bersih, diperoleh nilai t-hitung 2,494 dan signifikan t 0,018> $\alpha=0,05$. Hasil tersebut mengindikasikan bahwa peningkatan DPK mempengaruhi pendapatan laba bersih.

Tingkat keberhasilan bank dapat dicerminkan melalui kemampuan pihak bank dalam memproses penghimpunan dana hingga penyaluraannya. Apabila terjadi peningkatan dana nasabah yang berhasil dihimpun oleh bank menunjukkan reputasi bank baik dimata masyarakat. Fungsi bank tidak akan berjalan sebagaimana mestinya jika tanpa adanya dana yang cukup untuk bank menyalurkannya kepada masyarakat. Maka dari itu, peningkatan penghimpunan jumlah DPK tentunya menjadi peluang perusahaan perbankan untuk mengalokasikan kembali dana. Bank syariah dapat memilih pembiayaan yang lebih menguntungkan dengan tingkat risiko yang rendah agar dapat mengoptimalkan pendapatan nilai laba bersih. Oleh karena itu, semakin meningkatnya jumlah DPK maka laba bersih mengalami peningkatan pula. Windi (2014), Nirwana and Septiarini (2015), Purnamasari (2018), Setiawan and Afrianti (2018), Chandra et al., (2019), Adawiya (2020), dan Muhammadinah, (2020) juga mengindikasikan hasil yang sama.

\section{Pengaruh Pembiayaan Musyarakah terhadap Laba Bersih}

Hasil perhitungan, didapatkan nilai thitung sebesar 6,946 dengan angka signifikan t $0,000<\alpha=0,05$. Hasil tersebut mengindikasikan bahwa pembiayaan musyarakah mempengaruhi laba bersih.

Perusahaan perbankan berperan menjadi lembaga perantara (financial intermediary) dalam menjalankan kegiatan bisnisnya dipengaruhi oleh pengalokasian dana. Pengalokasian dana musyarakah berpotensi menghasilkan keuntungan serta meningkatkan penghasilan bank syariah dan tentunya akan berpengaruh juga terhadap peningkatan pendapatan laba bersih. Bank akan melakukan upaya peningkatan laba dengan memaksimalkan penyaluran pembiayaan kepada masyarakat. Pengoptimalan penyaluran pembiayaan ini diharapkan mampu menghasilkan keuntungan yang tinggi, sehingga akan semakin tinggi pendapatan yang diterima oleh bank Hal ini dikarenakan sumber utama penghasilan yang diterima pihak bank berasal dari jumlah penyaluran pembiayaan. Muhammad Busthomi (2014), Afif and Mawardi (2015), Monika (2019), Muhammadinah (2020), Nurhamidah and Diana (2021), dan Agustina, Sulaeman and Kartini (2021) juga memiliki hasil penelitian serupa.

Pengaruh Pembiayaan Musyarakah antara Dana Pihak Ketiga (DPK) terhadap Laba Bersih

DPK secara langsung dapat mempengaruhi dependen variable laba bersih ataupun secara tidak langsung dengan menggunakan variabel mediator pembiayaan musyarakah. Maka dinyatakan terjadinya partial mediation.

Sumber pendanaan terpenting dan paling utama pada perbankan syariah yakni dana simpanan dari pihak ketiga. Tingginya peningkatan jumlah penghimpunan atau dana simpanan pihak ketiga akan berdampak pada penyaluran atau pengalokasian dana. Bisa diartikan jika jumlah dana pihak ketiga semakin meningkat maka 
penyaluran dana kepada masyarakat akan meningkat pula. Bank sebagai lembaga perantara haruslah menjalankan fungsinya dengan melakukan pengoptimalan dana yang telah dihimpun. Muhammadinah (2020) dan Ito Hasibuan (2019) juga memiliki hasil penelitian serupa.

\section{PENUTUP}

\subsection{Kesimpulan}

Penelitian mempunyai tujuan untuk menguji faktor-faktor penentu Laba Bersih. Berdasarkan pengujian yang diperoleh maka didapatkan kesimpulan yaitu, Dana Pihak Ketiga (DPK) mempengaruhi Pembiayaan Musyarakah, pernyataan ini membuktikan kalau kenaikan DPK dapat juga meningkatkan Pembiayaan Musyarakah, sebab sumber pendanaan utama dalam penyaluran dana akad musyarakah yakni DPK. Dana Pihak Ketiga (DPK) mempengaruhi Laba Bersih, hal ini dapat dilihat dari pengalokasian DPK pada pembiayaan yang tentunya menghasilkan keuntungan pembiayaan yang memaksimalkan pendapatan laba bersih. Pembiayaan Musyarakah mempengaruhi Laba Bersih, hal ini membuktikan pada penyaluran dana musyarakah yang meningkat mempengaruhi pendapatan laba bersih, sebab pembiayaan musyarakah berpotensi mendapatkan keuntungan sehingga meningkatkan pendapatan laba bersih. Pembiayaan Musyarakah memediasi Dana Pihak Ketiga (DPK) yang mempengaruhi Laba Bersih, sebab perbankan Syariah memakai dana yang dikumpulkan untuk kemudian dialokasikan kembali pada produk penyaluran dana akad musyarakah tentunya untuk memaksimalkan pemasukan laba bersih. Maka dapat dipastikan adanya hubungan antara DPK dan pembiayaan musyarakah.

\subsection{Implikasi Penelitian}

Berdasarkan hasil kajian penelitian, diperoleh implikasi penelitian sebagai berikut:

a. Implikasi Teoritis, hasil riset ini sangat berkontribusi dalam ilmu pengetahuan, khususnya dalam pengembangan ilmu serta wawasan pada bidang perbankan syariah. Untuk periset berikutnya, dinantikan penggunaan variabel yang diduga berpengaruh terhadap laba bersih, serta menambah periode waktu penelitian dan objek yang diteliti juga di tambahkan. Sehingga diperoleh hasil penelitian yang jauh lebih baik dan memadai. Selain itu, pada riset ini terlihat adanya hubungan antara penyaluran dan pengalokasian dana dengan pendapatan laba yang meningkat ataupun menurun.

b. Implikasi Praktis, hasil riset berkontribusi untuk mendukung perusahaan perbankan agar lebih meningkatkan lagi pendapatan DPK. Sebaiknya, bank harus menunjukan keunggulan produk maupun jasa yang dimilikinya kepada masyarakat luas melalui berbagai cara seperti kemudahan dalam bertransaksi serta menawarkan jasa dan produk menarik melalui promosi yang kemudian mampu menarik minat nasabah untuk menyimpan dana. Hal ini mampu meningkatkan pula pengalokasian dana yang berpotensi menghasilkan keuntungan bank syariah yang tentunya akan berpengaruh terhadap pendapatan laba bersih. Selain itu, hasil riset ini juga dapat digunakan sebagai 
bahan pertimbangan yang bermanfaat untuk pengambilan keputusan investasi bagi suatu industri.

\subsection{Saran}

Berdasarkan kajian riset, diperoleh pengajuan saran sebagai berikut:

a. Bagi praktis, untuk terus meningkatkan perolehan DPK serta mengoptimalisasi perolehan laba bersih dalam menyalurkan pembiayaan musyarakah. Jika reputasi suatu bank syariah baik tentunya meningkatkan kepercayaan masyarakat terhadap bank. Maka hal ini berdampak pada perolehan laba bersih.

b. Bagi akademis, penelitian ini dapat dipergunakan untuk melengkapi kajian suatu riset. Karna dapat dijadikan sumber informasi, referensi dan wawasan dalam menambah kajian atau literature untuk riset selanjutnya.

\section{DAFTAR PUSTAKA}

Abdul Rahman, A., Mohd Nor, S. and Salmat, M. F. (2020) 'The application of venture capital strategies to musharakah financing', Journal of Islamic Accounting and Business Research, 11(3), pp. 827-844.

Adawiya, R. El (2020) 'Analisis Faktor-Faktor Yang Mempengaruhi Laba Bersih Bank Umum Syariah Di Indonesia', Journal of Enterprise and Development, 2(1), pp. 018.

Agustina, A. I., Sulaeman and Kartini, T. (2021) 'Pengaruh Pendapatan Margin Murabahah dan Pendapatan Bagi Hasil Musyarakah terhadap Laba Bersih', Al Maal: Journal of Islamic Economics and Banking, 2(2), pp. 179-192.

Almunawwaroh, M. and Marlina, R. (2017) 'Analisis Pengaruh Pembiayaan Musyarakah Terhadap Profitablitas Bank Syariah Di Indonesia', Jurnal Akutansi, 12(2), pp. 177-190.

Aziza, R. V. S., and Mulazid, A. S. (2017) 'Analisis Pengaruh Dana Pihak Ketiga , Non Performing Financing, Capital Adequacy Ratio, Modal Sendiri Dan Marjin Keuntungan Terhadap Pembiayaan Murabahah', Jebi (Jurnal Ekonomi Dan Bisnis Islam), 2(1)., 2(1), pp. 14-15.

Bernardin, D. E. Y. and Pebryyanti, D. I. (2016) 'Nilai Harga Saham Yang Dipengaruhi Oleh Laba Bersih dan Ukuran Perusahaan', Jurnal Ecodemica, 4(1), pp. 74-85.

Chandra et al. (2019) 'Pengaruh BI Rate, Dana Pihak Ketiga , Net Interest Margin , terhadap Laba Bersih di Perusahaan Perbankan yang Terdaftar di Bursa Efek Indonesia Periode 2013-2016', Owner (Riset Dan Jurnal Akuntansi), 3(2), pp. 195202.

Destiana, R. (2016). Analisis Dana Pihak Ketiga dan Risiko Terhadap Pembiayaan Mudharabah dan Musyarakah Pada Bank Syariah di Indonesia. Jurnal Logika, XVII(2), pp. 42-54.

Elidar et al. (2020) 'The Third Party Fund and its Impact on Mudarabah Financing: An Empirical Analysis of Islamic Banks in Aceh, Indonesia',pp. 1-5. 
Fatmawati, I., Puspitasari, N. and Singgih, M. (2016) 'Pengaruh Pembiayaan Murabahah, Mudharabah, Musyarakah Dan Ijarah Terhadap Laba Bersih Bank Umum Syariah Di Indonesia', Skripsi. Fakultas Ekonomi. Universitas Jember.

Fitri, M. (2016) 'Peran Dana Pihak Ketiga Dalam Kinerja Lembaga Pembiayaan Syariah Dan Faktor-Faktor Yang Memengaruhinya', Economica: Jurnal Ekonomi Islam, VII(1), pp. 73-95.

Hasrina, C. D. and Dasmi, K. (2019) 'Pengaruh Financing to Asset Ratio , Financing to Deposit Ratio , dan Dana Pihak Ketiga terhadap Pembiayaan Musyarakah pada Bank Umum Syariah yang terdaftar di Bursa Efek Indonesia', Jurnal Pendidikan, Sains, dan Humaniora, 7(2), pp. 165-170.

Juliansyah, N. (2011) Metodologi Penelitian: Skripsi, Tesis, Disertasi, Dan Karya Ilmiah. Jakarta: Penerbit Kencana Prenada Media Group.

Lidyah, R. et al. (2019) 'Pengujian Financing To Deposit Ratio Sebagai Mediasi Antara Pembiayaan, Non Performing Financing Dan Biaya Operasional Pendapatan Pada Bank Umum Syariah Di Indonesia', I-Finance: a Research Journal on Islamic Finance, 05(02), pp. 181-200.

Lisa, O. (2016) 'Determinants Distribution of Financing and the Implications to Profitability: Empirical Study on Cooperative Sharia Baitul Maal wa Tamwil (BMT) in Indonesia', Asian Journal of Accounting Research, 1(2), pp. 44-51.

Manurung, R. (2014) Analisis Jalur. Jakarta.

Merliana, C. and Fitri, M. (2016) 'Pengaruh Operasional, Dana Pihak Ketiga dan Non Performing Finance Terhadap Pertumbuhan Laba Pada Perbankan Syariah di Indonesia', Jurnal Ilmiah Mahasiswa Ekonomi Akuntansi (JIMEKA), 1(1), pp. 245257.

Monika, S. (2019) 'Pengaruh Pembiayaan Mudharabah Dan Pembiayaan Murabahah Terhadap Laba Bersih Pada Bank Syariah Mandiri Periode 2016-2018', Science of Management and Students Research Journal, 1(3), pp. 113-122.

Muhammadinah (2020) 'Pengaruh Office Channeling dan Dana Pihak Ketiga terhadap Laba dengan Pembiayaan Sebagai Variabel Intervening pada Perbankan Syariah di Indonesia', Iqtishodia : Jurnal Ekonomi Syariah, 5, pp. 40-46.

Muhammadinah (2020) 'Pengaruh Office Channeling dan Dana Pihak Ketiga Terhadap Laba dengan Pembiayaan Sebagai Variabel Intervening pada Perbankan Syariah di Indonesia', J-EBIS (Jurnal Ekonomi dan Bisnis Islam), 5(2), pp. $187-202$.

Nirwana, L. P., and Septiarini, D. F. (2015) 'Pengaruh Pertumbuhan Dana Pihak Ketiga terhdap Laba Bersih di Indonesia', Jurnal Ekonomi Syariah Teori dan Terapan, 2(8), pp. 642-657.

Nurhamidah, C. and Diana, N. (2021) 'Pengaruh Pembiayaan Mudharabah dan Pembiayaaan Musyarakah terhadap Laba Bersih Bank Syariah', Jurnal Maps (Manajemen Perbankan Syariah), 4(2), pp. 22-35.

Putra, G. J. and Djazari., M. (2019) 'Pengaruh Mudharabah, Musyarakah dan Murabahah Terhadap Laba Bersih Pada Bank Bni Syariah', Kajian Pendidikan Akuntansi Indonesia, 8(7), pp. 115-124. 
Setiawan (2015) 'Determinan Penentu Pertumbuhan Dana Pihak Ketiga Perbankan Syariah Di Indonesia', Jurnal Maps (Manajemen Perbankan Syariah), 1(2), pp. 1-9. Setiawan, D. and Afrianti, D. (2018) 'Pengaruh Dana Pihak Ketiga Terhadap Pemberian Kredit dan Laba Bersih Bank (Studi Kasus Pada PT. Bank Rakyat Indonesia(Persero),Tbk Kantor Cabang Majalaya Unit Dayeuhkolot)', Akurat, 9(3), pp. 1-20.

Setiawan, U. N. A. and Indriani, A. (2016) 'Pengaruh Dana Pihak Ketiga (DPK), Capital Adequacy Ratio (CAR), dan Non Performing Financing (NPF) terhadap Profitabilitas Bank Syariah dengan Pembiayaan sebagai Variabel Intervening', Diponegoro Journal Of Management, 5(4), pp. 1-11.

Sugiyono (2012) Metode Penelitian Kuantitatif Kualitatif dan REDD. Bandung: Alfabeta.

Suliyanto (2011) Ekonometrika Terapan: Teori dan Aplikasi dengan SPSS. Yogyakarta: Andi Offset.

Sumadi and Romdhoni, A. H. (2018) 'Pengaruh Financing To Deposit Ratio (FDR), Dana Pihak Ketiga (Dpk) Dan Return on Asset (Roa) Terhadap Pembiayaan Musyarakah', Jurnal Ilmiah Edunomika, 2(02), pp. 598-608.

Umam, K. (2016) Perbankan Syariah: Dasar-Dasar dan Dinamika Perkembangannya di Indonesia. Depok: PT. Raja Grafindo Persada.

Widyastuti, S. and Hendrieanto, M. B. (2010) 'Pengaruh Volume Pembiayaan, Dana Pihak Ketiga, dan Biaya Intermediasi Terhadap Marjin Laba pada Bank Umum Syariah di Indonesia', Jurnal Kajian Bisnis dan Manajemen, 12(1), pp. 115-124.

Winarto, H. and Nuraisyah, E. (2019) 'Analisis Pengaruh Pendapatan Margin Murabahah Dan Pendapatan Bagi Hasil Musyarakah Terhadap Laba Bersih Pt Bank Negara Indonesia Syariah (Periode Tahun 2012 - 2018)', Jurnal Akuntansi dan Bisnis Krisnadwipayana, 6(3), pp. 64-71.

www.bisnis.com

www.iaiglobal.or.id

www.ojk.go.id 